The International Journal of Indian Psychology: Volume: 01 | Issue: 04 | ISSN 2348-5396

\title{
Peer-group context insecurity' in upper and lower class youth
}

\author{
Mr. Sandipkumar N. Patel*
}

\begin{abstract}
:
Present study represents a comparative account of 'Insecurity' in upper and lower class youth. Here we have chosen 18 to 35 years old fellows in both upper and lower class category. Insecurity measurement was carried out by using 'Scale of Insecurity' created by Dr. Beena Shah. After statistical analysis of all data, we found vast different in degree of Insecurity between Upper and lower class youth. We have studied School context Insecurity by taking three independent variables using F-Anova test with 2x2x2 factorial design.
\end{abstract}

\section{KEYWARDS:}

Insecurity; School context Insecurity; F-Anova test

\section{INTRODUCTION:}

Man interacts with man by many ways during his whole life and strikes with many hurdles while interacting with such biotic factors. He faces many state of his own mind. One of these state is Inferiority complex. When man does not get his basic requirements, he gradually develops Inferiority complex in his mind. And this Inferiority complex gradually develops in to 'Insecurity'. Insecurity means "The Inferiority complex created due to the external factors/catalysis of surrounding environment". Moreover Dr Sigmund Freund said that man suffered by inferiority complex with rather higher intensity in groups. Here we try to measure the degree of Peer Group-context Insecurity by taking three independent variables in account (Raja, 1982).

\section{OBJECTIVES:}

- $\quad$ To measure degree of Peer Group context Insecurity in upper and lower class youth

- $\quad$ To compare degree of Peer Group context Insecurity between upper and lower class youth

\footnotetext{
*Research Scholar, Department of psychology, Sardar Patel University, Vallabh Vidyanagar, Gujarat 


\section{RESEARCH METHODOLOGY:}

(Dhila, 2004; Shah, 1989)

- Independent Variables

\begin{tabular}{|l|l|}
\hline $\mathrm{A}=$ Economical Status & $\mathrm{A}_{1}=$ Upper class (Annual income $>20,000$ rupees) \\
\hline & $\mathrm{A}_{2}=$ Lower class(Annual income $\leq 20,000$ rupees) \\
\hline $\mathrm{B}=$ ArealLocation & $\mathrm{B}_{1}=$ City (Town) \\
\hline & $\mathrm{B}_{2}=$ Rural \\
\hline $\mathrm{C}=$ Sex & $\mathrm{C}_{1}=$ Boys \\
\hline & $\mathrm{C}_{2}=$ Girl \\
\hline
\end{tabular}

- $\quad$ Dependent Variables

Degree of Peer Group context Insecurity

\section{HYPOTHESIS:}

$\mathrm{Ho}_{1}$ : There is no significant difference between Means(M) of the degree of Peer Group context Insecurity between Upper and lower class youth.

$\mathrm{Ho}_{2}$ : There is no significant difference between Means(M) of the degree of Peer Group context Insecurity between city and rural area youth.

$\mathrm{Ho}_{3}$ : There is no significant difference between Means(M) of the degree of Peer Group context Insecurity between boys and girls.

\section{TOOLS:}

- Personal information sheet

- Insecurity measurement scale (Dr. Beena Shah)

- Statistical analysis of data by F-Anova test using 2x2x2 factorial design

\section{SAMPLE:}

Total 240 youngsters were selected. Out of 240, 120 were of Upper class and 120 were of lower class. Out of these 120, 60 were from city/town area and 60 were from rural area. Sex ratio was maintained 1:1 in this sample of 60 . It means out of these 60,30 were boys and 30 were girls. 
The International Journal of Indian Psychology: Volume: 01 | Issue: 04 | ISSN 2348-5396 STATISTICAL ANALYSIS:

(Parekh and Dixit, 1995)

Table -1

Summary of the $2 \times 2 \times 2$ analysis of variance based on degree of Peer Group context Insecurity with respect to three independent variables

\begin{tabular}{|c|c|c|c|c|c|}
\hline $\begin{array}{c}\text { Score } \\
\text { of } \\
\text { Variable }\end{array}$ & $\begin{array}{l}\text { Sum of } \\
\text { Square }\end{array}$ & DF & $\begin{array}{c}\text { Mean of } \\
\text { Square }\end{array}$ & $\mathbf{F}$ & Sig. \\
\hline Status (A) & 611.204 & 1 & 1.204 & 11.29 & 0.01 \\
\hline Aria (B) & 5.704 & 1 & 5.704 & 5.33 & 0.01 \\
\hline Sex (C) & 49.504 & 1 & 49.504 & 4.62 & N.S. \\
\hline $\mathrm{A} \times \mathrm{B}$ & 44.204 & 1 & 44.204 & 4.12 & N.S. \\
\hline $\mathrm{B} \times \mathrm{C}$ & 27.334 & 1 & 27.339 & 2.55 & N.S. \\
\hline $\mathrm{A} \times \mathrm{C}$ & 71.504 & 1 & 71.504 & 6.58 & 0.05 \\
\hline$A \times B \times C$ & 105.337 & $\mathrm{1}$ & 105.337 & 9.84 & 0.01 \\
\hline
\end{tabular}

Table -2

Mean Scores and difference of Mean degree of Peer Group Peer Group Insecurity with respect to three independent variables

\begin{tabular}{|c|c|c|c|c|}
\hline \multicolumn{2}{|c|}{ Independent Variables } & N & Mean(M) & $\begin{array}{c}\text { Difference } \\
\text { Of Mean }\end{array}$ \\
\hline \multirow{2}{*}{ Status (A) } & Upper & 120 & 12.18 & \multirow{2}{*}{3.2} \\
\cline { 2 - 4 } & Lower & 120 & 8.98 & \multirow{2}{*}{0.3} \\
\hline \multirow{2}{*}{ Aria (B) } & City(Town) & 120 & 10.43 & \multirow{2}{*}{6.9} \\
\cline { 2 - 5 } & Rural & 120 & 10.73 & \\
\hline \multirow{2}{*}{ Sex (C) } & Boys & 120 & 10.73 & 11.03 \\
\cline { 2 - 5 } & Girls & 120 & & \\
\hline
\end{tabular}




\section{RESULTS AND DISCUSSION:}

$\mathrm{Ho}_{1}$ : There is no significant difference between Means(M) of the degree of Peer Group context Insecurity between Upper and lower class youth.

The ' $\mathrm{F}$ - Value' for first set of independent variables were shown in table-1. This result has 0.01 significance value. So above said hypothesis Ho1 cannot be accepted because result has significant difference. Thus statistical data of table-1 clearly shown that there is significant difference in the degrees of Peer Group context Insecurity between Upper and lower class youth.

$\mathrm{Ho}_{2}$ : There is no significant difference between Means(M) of the degree of Peer Group context Insecurity between city and rural area youth.

The 'F - Value' for second set of independent variables were shown in table-1. This result has 0.01 significance value. So above said hypothesis $\mathbf{H o}_{2}$ cannot be accepted because result has significant difference. Thus statistical data of table-1 clearly shown that there is significant difference in the degrees of Peer Group context Insecurity between city and rural area youth. Mean values for city and rural area were 11.09 and 8.05 respectively (Table-2). These mean values concluded that the degree of Peer Group context Insecurity is significantly higher in city area than that rural area youth.

$\mathrm{Ho}_{3}$ : There is no significant difference between Means(M) of the degree of Peer Group context Insecurity between boys and girls.

The ' $\mathrm{F}$ - Value' for first independent variables were shown in table-1. This result has no significance value. So above said hypothesis $\mathbf{H o}_{3}$ can be accepted because result has significant difference. Thus statistical data of table- 1 clearly shown that there is no significant difference in the degrees of Peer Group context Insecurity between boys and girls.

\section{CONCLUSION:}

Finally we can conclude this study in following three conclusions:

- Peer Group context Insecurity is significantly higher in lower class than that of upper class.

- Peer Group context Insecurity is almost equal in city area than that rural area youth.

- Peer Group context Insecurity is insignificantly differ between girls and boys. 
The International Journal of Indian Psychology: Volume: 01 | Issue: 04 | ISSN 2348-5396 REFERENCE:

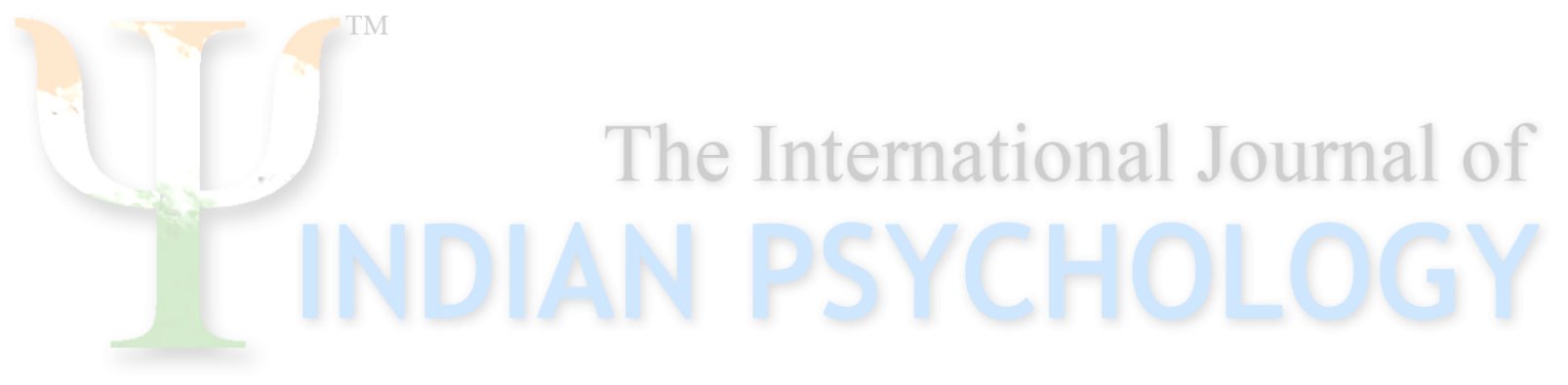

